\title{
WHY DO PEOPLE SEE A FINANCIAL SYSTEM AS A WHOLE VERY IMPORTANT?
}

\author{
Dian Masyita ${ }^{1}$
}

\begin{abstract}
The action of one person will affect the others and then the action of one country will affect other countries. Financial crisis is like a contagious disease, which spreads everywhere. The failure in capturing systemic risk is the interconnected market events ('network externalities') can produce self-reinforcing cycles then create the harmful situation. What happened in the banking regulation particularly Basel II? In reality, Basel II did not work completely in 2008. Since the implementation of risk management based on Basel II has been a prerequisite for a bank, it is supposed to make a positive impact. Misplaced reliance on mathematical model and statistics in managing risk could one of the problems in the decision making process. Using system thinking, system dynamics paradigm and theory of feedback system, this paper tries to see the risk management from different perspective and to enrich the understanding of how financial systems work: what drives them and causes the behavior. Many lessons can be learnt from this financial contagion since Islamic banking and finance system has inevitably been a part of the international financial systems.
\end{abstract}

Keywords: Financial crisis, interconnected events, system thinking, system dynamics, islamic banking and finance.

JEL Classification: D10, D80, E50, E60, G20, G32

1 Author is Associate Professor, Faculty of Economics and Business, University of Padjadjaran, 35 Dipati Ukur, 40132 Bandung - Indonesia 


\section{INTRODUCTION}

Joseph Stiglitz says that financial crisis is like a contagious disease, which spreads everywhere. The action of one person will affect the others and then the action of one country will affect other countries. He states that interconnected market events ('network externalities') can produce self-reinforcing cycles which create the harmful situation. This happened in Asian Financial Crisis in 1997 started in Thailand and spread to Indonesia, Korea, and other countries. After celebrating the ten years anniversary of 1997 Asian Crisis, global financial crisis happened. It started in the United States spread to United Kingdom, Europe and other countries. In 2008 global financial crisis, serious financial problems emerged simultaneously in many different countries. Its economic impact is felt throughout the world as a result of the augmented interconnectedness of the global economy. When the country more integrated, more interdependent, there is a greater necessity interconnected action.

Why did no-one see the credit crunch was on its way? The interesting and challenging question came from Queen Elisabeth when she visited The London School of Economics (LSE) in November 2008. This simple question basically was not an easy question to be answered. It needed 7 months for British Academy to prepare the answers. In order to answer that question, The British Academy convened a forum on 17 June 2009 attended by 33 professors of economics and financial experts. The results of that meeting were summarized in a letter to Queen on $22^{\text {nd }}$ of July 2009 as an attempt to explain why economists missed this financial crisis.

There are some important points in that letter. First, there were many warnings about imbalances in financial markets and the global economy, but people have great difficulty seeing the risk to the system as a whole rather than to any specific financial instruments. Second, risk calculations were most often confined to slices of financial activity, using some of the best mathematical minds but they frequently lost sight of the bigger picture. Third, these conditions were fuelled by the increase of house prices both in the UK and USA. Alarm bells started to ring but "against those who warned, most were convinced that the financial wizards had found new and clever ways of managing risks" (British-Academy, July 22, 2009). 
Next questions came up, why did it happen? Why do people see a system as a whole very important? What were the causes of global financial crisis?

Based on the holistic approach in understanding the problem of a system, this paper identifies the critical factors of an integrated and interdependent financial system and to assure them can be recognized and avoided in the future for developing Islamic banking and finance system (IBF).

\section{LITERATURE REVIEW}

\subsection{The Failure of Risk Management}

All the banking sectors have risk management division. Basel I, II and also Basel III had been implemented entirely in the banking industry. Risk management team refers to the overall process; 'to define a business strategy, identify, quantify those risks, understand and control the nature of risks'(Cumming \& Hirtle, 2001). In one occasion, Professor Tim Besley said that one of the UK major banks had 4000 risk managers because risk management was considered an important part of financial markets. Even having more risk managers, that bank still faced the big problems because "those intelligent people were surprisingly difficult in seeing the risk to the system as a whole rather than to any specific financial instrument or loan" (BritishAcademy, July 22, 2009).

\subsubsection{Misplace reliance on risk management model}

The other cause of crisis driven by the economic researcher and financial market practitioners is they became very focus on the quantitative method and tended to use the short data period. Misplaced reliance on mathematical model and statistics in managing risk is one of the problems in the decision making process. Short-term observation periods plus assumption of normal distribution can lead to large underestimation of probability of extreme loss events. The models are generated by the empirical correlation which mostly untrue with the more data. That was the reason why failure to capture fat-tail risks occurred. The other failure in capturing systemic risk is 
interconnected market events can produce self-reinforcing cycles where models do not capture.

The other problem of mathematical economics is the models are too good. They have a limitation that they only can be implied to the certain circumstances and we cannot generalize them. Furthermore, the increasing complexity of securitized credit required credit rating techniques were applied to new varieties of structured security, where no historic record existed. "These ratings proved highly imperfect predictors of risk and were subject to rapid rating downgrades once the crisis broke" (The Turner Review, A regulator response to the global banking crisis, March 2009). Therefore, the regulator should give more attention to what happened if every bank using the same risks models. If the result of risk model forecasting is a recommendation to dump the stock and all the bankers react over it at the same time, the stock price will collapse.

\subsection{Behaviour}

\subsubsection{Role of the Regulator}

"Don't ever forget the history", the statement of Indonesian first President, Ir. Soekarno is relevant to start the understanding of financial crisis. In line with the statement above, Siddiqi also states that "Knowledge of history may save us from repeating mistakes and encouraging us onto following into footsteps of those who succeeded" (Mohammed N. Siddiqi, 2008: 4). Being inspired by those people, we do recognize that there was a long history of the role of regulators in regulated the banking sectors failed. It is most crucial to learn about its evolution, and a better understanding of this evolution requires knowledge of its beginnings.

The great depression in 1930s proved that banks had enormous failures experiences, led to mistrust of the whole banking system especially a crisis in liquidity. The US government helped to solve this problem through the creation of the Glass-Steagall act in 1933. In an article, "The Financial Meltdown, How did we get in this mess", Philip Protter (2008) wrote the important information to understand the cause of crisis. 
'The repeal of the Glass-Steagall act came in two steps. In the 1970s it became stylish in the United States to favor de-regulation. The next big step was for the Savings and Loan (S\&LS) Industry, with the Depository Institutions Deregulation and Monetary Control Act of 1980, under President Reagan. The S\&LS went from being tightly regulated with insured deposits (up to $\$ 100,000$ per account), to deregulate with insured deposits. Two things happened: (1) the directors of S\&LS began to behave in a high risk manner in the search for higher profits, and (2) unethical people began in effect to steal from the bank, through many different means... These eventually led to massive $S \& L$ failures, and the necessity of the government (with the FDIC being committed by law) to bail out the depositors, at the expense of the taxpayers. Under strict regulation S\&LS retained mortgage loans they initiated. After deregulation a new business model emerged: the S\&LS and banks could originate mortgages and then sell them on the open market. The S\&Ls would retain the servicing part of the mortgage, and earn through fees: by servicing the mortgages and by origination fees'.

Based on system thinking perspectives, information above is very important to recognize the root cause of problems. The first lesson that we can learn from the article above is how the regulator decision made a huge impact for the system. The policy makers, in this term are the regulators, may create unanticipated side effects. Many experiences, from Thomas More in 1516 to Pogo in the mid $20^{\text {th }}$ century, have long been acknowledged that people trying to solve a problem often make it worse ${ }^{2}$ (Sterman, 2000: 5). Forrester calls such phenomena the "counterintuitive behavior of social systems" (Forrester, 1971a). The government attempted to stabilize the systems might destabilize them. The government responded the great depression by imposing many regulations. The system responded to the intervention in ways the government did not anticipate. Thus, the

2 There are many statements of counterintuitive behavior. Some of them are "...and it will fall out as in a complication of diseases, that by applying a remedy to one sore, you will provoke another, and that which removes the one ill symptom produces others..."(Sir Thomas More). "...Anything that can go wrong will go wrong"(Murphy). "We have met the enemy and he is us." (Pogo). 
unanticipated consequences continued, became specific behaviors and burst periodically until the next 75 years.

\subsubsection{Creation of financial derivative product and role of their actors}

Basel I and II impose the banks to maintain capital reserves. However, it is costly for banks to maintain capital reserves. This requirement makes bank create less money and at the same time there were the high level of competition among banks. These competitions make matters worse. Competition would force many of them to behave aggressively to find and create the alternative products especially after "dot-com" era crashed. Few financial engineers created and sold derivative financial products around the world. The Fed, as the regulator, has a pivotal role in the creation of derivative products. According to The Turner Review (2009), securitized credit has played a major role in mortgage lending as follows;

From the mid-1990s the system entered explosive growth in both scale and complexity: (1) with huge growth in the value of the total stock of credit securities, (2) an explosion in the complexity of the securities sold, with the growth of the alphabet soup of structured credit products; and (3) with the related explosion of the volume of credit derivatives, enabling investors and traders to hedge underlying credit exposures, or to create synthetic credit exposures. (The Turner Review, A regulator response to the global banking crisis, March 2009: 16)

It resulted not only in massive growth of securitized credit, but also in a profound change in the nature of the securitized credit model in the world.

\subsubsection{Sub-prime Mortgage}

What did the bankers mean about the sub-prime mortgage? With very low down payment system for buying a mortgage, two conditions happened; (1) The home owners got the money when the 
price goes up (capital gain) and (2) they did not lose anything when the price goes down. Who benefited from this condition? Joseph Stiglitz said 'it is a something weird. It is not particularly the American business model of the American banking in which gave money to the poor. Giving money for the CEO is one thing" he said in one Lecture seminar series ${ }^{3}$. Because of sub-prime mortgage problem, there were many US citizens lost their home and their entire life savings.

That is already clear that the toxic financial product created by the bankers for reasons that people should suspicious. It raises the next question, what were the bankers doing? What were they thinking when launch these toxic products? The regulator must ask the questions are like those before giving approval.

The creators of toxic mortgages created piece of papers and then sold them to the people around the world who greedy enough to buy them. They found these people and made a lot of money. Thus, they obtained a huge bonus for founding these greedy people to gamble. It is clear now that the problem is the design of incentive package. The expert says "incentive matters". The design of incentive had excessive risk to gamble. Meanwhile households benefited from ready credit and businesses benefited from lower borrowing costs in the short term. The government benefited from high tax revenues. There was a broad compromise that it was better to cope with the consequences of bubbles. Then, it emerges the question, where was the problem? Besley and team explained this situation in their letter to Queen as follows:

....Everybody looks as if they are doing their own work appropriately. Even in accordance with the standard measurement of success, they were often doing it well, partially. The failure was to see how collectively this added up to a series of interconnected imbalances over which no single authority had jurisdiction... Individual risks may rightly have been viewed as small, but the risk to the system as a whole was vast (British-Academy, July 22, 2009).

3 LSE's Public Event on Monday, 25 February 2008 with title "The $\$ 3$ Trillion War: the true cost of the war in Iraq". 
According to British Academy, 'the failure of the collective imagination of many intelligent people internationally to understand the risks to the system as a whole is the best reason for this'. By launching sub-prime mortgage loan, the creators have created a trigger, more demand for purchasing houses. Those demands then create the higher mortgage-backed asset value in the banking system. When business investments drop, it would decline the household income. This situation caused most loans default. As a result, the banking falls into bankruptcy. The chain reactions show a vicious cycle in the whole banking system. "As a vicious cycle, affordable payment drops further, equivalently, mortgage repayment drops further" (An, Subramanian, \& King, 2009).

\subsubsection{Conflict of interest of the rating agency}

When financial crisis happened in 1997, where were the rating agencies? They failed to do their duties. Until the day before Thailand crisis, they still gave Thailand AAA ratings and the next day they downgraded the ratings. Down grading two grades or more very quickly creates the new problems. The investment fund companies sold their ownership of the low grades banking. In the short time, the share prices of banking sectors plummeted to the ground. The rating agencies created the problems. Ten years went by, in 2007 the rating agencies built up the same reputation with their reputation in 1997. It was even the worst. What happened in the banking regulation particularly Basel II? Basel II could not prevent the global financial crisis in 2008 or the other word Basel II did not work at all.

Since the implementation of risk management based on Basel II has been a prerequisite for a bank, it is supposed to make a positive impact. But in reality, risk management did not work to prevent the crisis. One of the problems is the risk management teams deeply reliance on the rating agency. Now, people do recognize how the judge a risk depends on the rating agency. If we look at the incentive structure of the rating agency, the rating agency is partly or fully paid by the banks. If these banks have toxic mortgages products, the conflict of interest is inevitable. The higher competition of the rating agency, the higher moral hazard occurs. Issue of incentive conflict is very important to be analyzed. "Incentives are employed as a preferred 
tool of policy in many areas of public life" (Grant \& Sugarman, 2004: 1). The role of the rating agency in financial business sectors is pivotal. A huge loophole in Basel 2 regulation is that no capital needs to be set aside if the investment is AAA, since it is then essentially totally safe. When a bank makes a risky investment, it needs to set aside a capital reserve equal to a percentage of the money at risk; the more the risk, the more is set aside. Therefore, banks need AAA rated investments to maintain the minimum capital reserves. The conflict of interest occurred between the rating agency and the bank they rated and created the derivative product. Furthermore, Grant and Sugarman (2004) states 'most of the time and in most areas of life, incentives are employed without ethical qualms. Instead, an incentive is a benefit designed as a motive or incitement to action'. Indeed, they argue that incentives are generally taken to be an ethically unproblematic approach to achieving public policy objectives.

\subsubsection{Incentive matters and greedy in financial}

Incentive structure of the rating agency is questionable. The bonus supplemented the base salary, and in most cases far outstripped the base salary, becoming the primary means of compensation. The system of bonuses focused the workforce of companies on short-term performance and short-term returns. Moreover, the banks or the investment companies hired their auditors as their consultants. It creates an incentive conflict because most the auditor income as a consultant bigger than his income as an employee of a large audit firm. "The incentive problems of auditors, together with the laissez faire attitude of the government, which led to the Enron debacle" (Protter, 2008).

\subsubsection{Role of Mass Media}

The role of the mass media in promoting the toxic mortgage is enormous. Media, conscious or not, is a propaganda tool for the bank and investment companies to promote and advertise their derivative products. Mass media also helps the government information in a proper way, not only to make people scare and create chaos, but also to create the trust. Therefore, media have double functions such as 
publish the bad news and the good news. However, media is a business entity. Media as a corporation have to create profits. Media need the big corporations to sponsor their activities. This generates vested interests between them. There are many comments from the government and the players of toxic mortgages, of course using the media to publish them, which have an extremely powerful impact to encourage people to invest in any sub-prime mortgages ${ }^{4}$. There are mutually exclusive relationship between media and corporations. Dean Alger (1998) quotes former top editor of the Chicago Tribunal, James Squires, concerning the escalating patterns of concentration of mediaownership in profit-orientated corporations: "In the starkest terms, the news media of the 1990s are a celebrity-oriented, Wall-Street dominated, profit-driven entertainment enterprise dedicated foremost to delivering advertising images to targeted groups of consumers" (Alger, 1998).

\section{FINANCIAL CRISIS AS A PRODUCT OF A COMPLEX FINANCIAL SYSTEM}

The global imbalance was generated by the United States as one country which has a detain power to other countries and international institutions almost in the whole world including the IMF and the World Bank. The IMF as an international institution did not do anything about the movement of toxic mortgages. Otherwise, The IMF's Global Financial Stability Report of April 2006 claims that the banking and overall financial system become more resilient because of the dispersion of credit risk to a broader and more diverse set of investors.

Despite the fact that many writers had written the articles and papers about financial crisis, Figure 1 shows the causal loop of global financial crisis in macro-view. This paper tries to create the understanding how these financial systems work: what drives them and causes the behavior. 


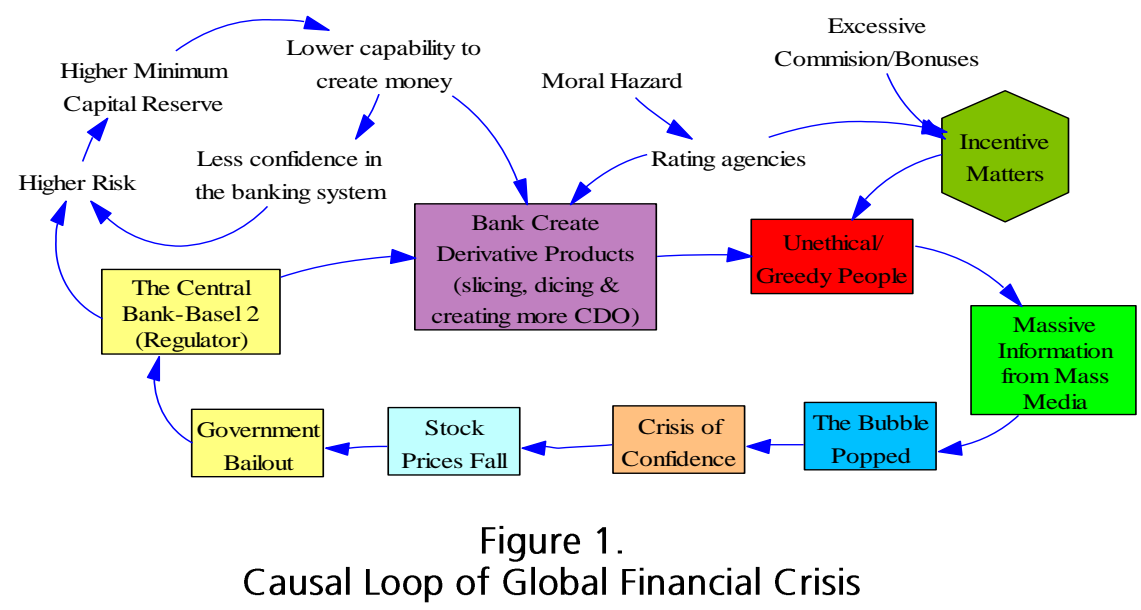

\subsection{What is a System?}

Before going any further with a complex system, we should understand what the meaning of a system. According to Collins Dictionary, a system is "the manner in which the parts of something fit or function together". Jay Forrester in his book, "Industrial Dynamics" (1968), stated that a system is a group of components simultaneously operates to achieve the specific goal. A system can also be classified as a group of entities acts and interacts all together to accomplish the reasonable aims. All systems interact with their environment. Ability to see a system as a whole is not an easy task. This is one of the reasons why no one sees the credit crunch on its way as The Queen questions in 2008. Therefore, it is totally necessary to have this skill in order to be able to control the system successfully.

One of the causes why we were not capable of understanding the system as a whole because our past education taught us to solve the problem with fragments them. Make them simple and in the short term we came up with a decision. Peter Senge (2006:1) explains the phenomena above clearly and concisely in his famous book "The Fifth Discipline" as follows:

From a very early age, we are taught to break apart problems, to fragment the world. This apparently makes complex tasks and subjects more manageable, but we pay 
a hidden, enormous price. We can no longer see the consequences of our actions; we lose our intrinsic sense of connection to a larger whole. When we then try to 'see the big picture' we try to reassemble the fragments in our minds, to list and organize all the pieces. But, as physicist David Bohm says, the task is futile - similar to trying to reassemble the fragments of a broken mirror to see a true reflection. Thus, after a while we give up trying to see the whole altogether.

Everyone made their own decision based on their expertise perspectives. Therefore, when researchers, public policy makers, managers focus only on their positions, they have little sense of responsibility for the results produced when all positions interact. Furthermore, when the results are unsatisfactory, it can be very difficult to know why. They have to pay enormous price for that, more trillion dollars, as we see today.

\subsection{What is the Study of Complex Systems?}

Complex systems are a new field of science which studying how the system interacts with its environment and creates the collective behaviors. There are some reasons why using the complex system approach to understand the system. First reason, the real world, where we live, is a picture of complex system. Second, the challenges the decision makers face is growing as the systems. Therefore, they must operate and manage the system that is becoming increasingly complex. To address challenges as such, the researcher need ability to develop knowledge about specific complex systems that can then be applied by the decision makers. People perceptions, banking sectors, financial institutions, rating agencies and regulators are the example of complex systems. These systems are interdependent with their environment.

The study of complex systems is about understanding indirect effects of each component in a system. Many problems appear every time in a system or inter system. A number of research methodologies make the complex system simple (parsimony). In a the IMF report, William White states that the financial crisis provides evidence that the 
simplifying assumptions on which much of modern macroeconomics is based were not useful in explaining real-world developments (White, December 2009: 16). The result of their researches mostly did not work in the real world especially in the field of social science, economy and business. They are difficult to be implemented because the nature of the system is not as simple as their models. In addition, the real world is also dynamics rather than static.

An organization can be seen as a complex system. The complexity of a system is determined by "the interaction of the following factors; the number of parts that make up the system, interactions and attributes between these parts, and the degree of organizations within the system" (Schoderberk, 1980: 5). System dynamics is a methodology to enhance learning in complex system and fundamentally interdisciplinary ${ }^{5}$. System dynamics is also as "a methodology for managerial problem solving" (Sushil, 1993: 1). Sterman's framework shows the System Dynamics modeling activity embedded in a "real world" system. It is arguable that his representation most faithfully captures the way in which modeling activity influences mental models and hence real world behavior. Wolstenholme and Coyle states that the function of system dynamics modeling, both quantitative and qualitative dimension, are to understand the process, information and organizational boundaries (Coyle, 1996: :Wolstenholme, 1990). The qualitative phase is required to start the quantitative modeling. The qualitative phase refers to the building of causal loop diagrams (CLDs), "as an understanding of the structure of the problem" (Radianti, 2008: 5). A good qualitative mapping process will reveal more information as the mental models of the clients.

Financial system is a system. Finance is not a pure discipline but multi discipline influenced by fields of economics, political science, social psychology, sociology and other social sciences. Financial stability also depends on various factors involved in the same time. Allen and Wood (2006) referred to financial instability as a phase in which a large number of parties experiences financial crises and are not warranted by their previous behavior and have seriously adverse macro-economic effects. Allen and Wood include the non-financial

5 See website www.systemdynamics.org to know system dynamics further. 
sector in this definition, explaining that financial institutions are not the only entities which experience financial stress (Allen \& Wood, 2006). Hence, the financial and social system, at times, exhibit behavior which is unexpected and counterintuitive (Sushil, 1993).

Other scientists use words to explain the verbal pictures of circular causal processes; vicious circles, self-fulfilling prophecies, homeostatic processes, and invisible hands. In particular cases we recognized the phrase "vicious circle" to refer to a continuing unpleasant situation that leads to its own worsening. A French writer wrote how the "vicious circle" works as follow: "I'd need rest to refresh my brain, and to get rest, it's necessary to travel, and, to travel, one must have money, and, in order to get money you have to work, create, etc.: I am in a vicious circle [cercle vicieux], from which it is impossible to escape" (Balzac, 1850). A financial system is a system which full of feedback processes inside it. In general, there are two types of feedback loops, positive (or self-reinforcing) and negative (self-correcting). Positive loops tend to reinforce or amplify whatever is happening in the system. Negative loops counteract and oppose change (balancing) the system.

System thinking is needed more than ever in deal with complexity (Checkland, 1981: :Richmond, 1993: :Senge, 1990). Despite system thinking is suitable for dealing with complex systems, most individuals have a great deal of difficulty thinking systemically (Maani \& Maharaj, 2001). Richmond says that there is a particular 'habits of thought' which make it difficult to think systemically and to learn in an interdependent reality. These habits grew in an environment which 'local' perspectives enabled us to do just fine (Richmond, 1994). The statement above remembers us to the content of a British Academy's letter to Queen Elizabeth. The failure of the collective imagination of people because of 'local' perspectives and inappropriate 'habits of thought' is the best reason for misunderstanding the system as a whole.

System thinking and complexity are interdisciplinary approach. To understand the behavior of a complex system as financial system, the economists must collaborate with system engineers, sociologists, psychologists, anthropologists and policy makers. The more understanding the system, the better policy can be formulated. 


\subsubsection{Islamic Concept for Interdisciplinary and Dynamics Perspectives}

As a paradigm, system thinking is a "world view" which seeing things holistic and interconnected. System thinking and dynamics complexity approach are not a new concept since Ibn Khaldūn (d. 808/1406) wrote an interdisciplinary and dynamics model of socioeconomic and political dynamics in the Muqaddimah, or 'Introduction' to his Kitāb al-'llbar (Book of Lessons) more than five hundred years ago. As an Islamic scholar, Ibn Khaldūn analyzes the rise and decline of the Muslims from a dynamic circular causation approach. Ibn Khaldūn's model does not ascribe the decline to a single cause. In Figure 2 lbn Khaldūn's model explores all sectors of society are closely interrelated. "If one decays, and this is not corrected, then it may serve as the trigger mechanism for the weakness of others and also, in turn, contribute to its own further decay" (Chapra, 2000: 175 ). As a social scientist, Ibn Khaldūn analyzes the causes and origins, or the how and why of the phenomena occurs and where the phenomena will go. Ibn Khaldūn's dynamics model consists of Sharī 'ah (S), political authority or Wāzi' $(G)$, people or rijāl $(N)$, wealth or stock of resources of $m \bar{a} l$ $(\mathrm{W})$, development or 'imārah (g), and justice of 'adl (j), in a circular and interdependent manner, each influencing the others and in turn being influenced by them (Chapra, 2000).

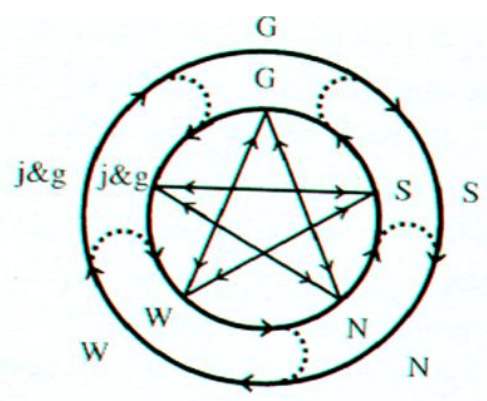

Figure 2.

Ibn Khaldūn's Interdisciplinary and Dynamics Model

It is crucial to put a new paradigm into economics scholar perspectives especially for Islamic banking, economics and finance scholars. Chapra says that the method of economics is also 
determined by its worldview. The difference worldview leads different activities, concepts, and policies. The terms well-being may be defined in a number of ways. "If well-being were defined in a purely material and hedonist sense, then it would be perfectly rational for economics to give prominence to the serving of self-interest and the maximization of wealth, bodily pleasures and sensual gratifications" (Chapra, 2000; 3). Conventional economics is totally ignoring the spiritual aspect. Fortunately, individuals do not always behave in a purely selfinterested manner as conventional economics has assumed, they also behave in an ideal or altruistic manner. Their behavior tends to fluctuate between these two extremes.

Either conventional or Islamic economics is a dynamics complex knowledge system in which has many variables, material, humanitarian and spiritual, involve in this systems. Khan (1987) argues that early Islamic thinkers like Abu Yusuf, Abu Ubaid, Yahya b.'Adam, Qudama b. Ja'far, al-Mawardi, Ghazali, Ibn Taimiyya, Ibn Khaldun, Shah Wali Ullah, Afghani and thinkers of recent past like Iqbal, Mawdudi, Bagar as Sadr have been concerned about Islamic economics is a multi-disciplinary subject and a normative discipline. They wrote about economic problems such as poverty, social justice, taxation, economic balance, market imperfections and role of the state. Islamic economist studies "the economic behavior through understanding the behavior and decision-making processes from interrelated behavior from the society at large" (Khan, 1987: 26). Historically, period between the Prophet's establishment of an Islamic community in Medina and the death of Imam Ali, called as a Golden Age, Islam permeated every aspect of human behavior and interaction. "The Islamic man's private religious practices constituted a wellintegrated part of a homogeneous Islamic system, characterized by its own particular social, political and economics practices" (Nomani \& Rahnema, 1994: 31).

\section{WHY DOES ISLAMIC FINANCE BECOME AN ALTERNATIVE SYSTEM?}

As general, Islamic Financial Institutions have to abide by the five pillars of Islamic finance, which are: '(1) The ban on interest, (2) the ban on uncertainty or speculation, (3) the ban on financing certain 
economic sectors: Financing of industries deemed unlawful by Sharia-such as weapons, pork, and gambling--is forbidden, (4) The profitand-loss-sharing principle and (5) The asset-backing principle: Each financial transaction must refer to a tangible, identifiable underlying asset' (Standard \& Poor's "Islamic Finance Outlook 2009"). At least, these pillars make the differences between IBF and the conventional ones particularly pillar no (2). Implementing these pillars is expected can minimize the effects of financial contagion. The financial crisis is generated by a moral failure of financial analyst, economist \& investment consultants which reliance on inadequate mathematical model in order to gain enormous benefit by telling people what they want to hear, even when it's wrong and through the creation of speculative financial product (Chapra, 2008: :Muhammad N. Siddiqi, October, 2008). They argue that if the Islamic principles related to economics and finance would be applied, then the financial crisis could have been prevented. Furthermore, Ahmed (2009:7) asserts that "greed led to excessive risk taking is one of the key elements that triggered the crisis, this problem cannot be resolved by preaching morality". He also states that the problems related to risks needs to be tackled at the institutional, organizational, and instruments levels by creating appropriate rules, support institutions and incentive structures.

Currently, most IBF institutions are still operating in the short term oriented investments. Asutay (2007) states that the Islamic financial industry being a part of the global financial markets and it is affected by the international standards. Then, he argues that "the realities of financial markets, which prioritize economic incentives rather than religious behavioral norms, thus, has forced IBF to become part of the international financial system by adopting the commercial banking model" (Asutay, 2007: 175). "Data analysis also shows that long-terms financing is not the norm for IBF, as most of the financing focused on projects with maturities lasting less than a year" (Asutay, 2009: 21)

\subsection{The Crucial Factors}

What are Banking and Financial (IBF) scholars able to learn from this crisis? When we refer to Figure 1 above, we realizes that most of 
those factors; regulations, derivative financial products, greedy or unethical people, conflict of interest of rating agency, incentive matters, misplaced rely on risk management model and role of mass media, do not something new in the structure of IBF system nowadays. Indeed, some of them have existed and embedded in IBF system. Let us look at each of the following factors.

\subsubsection{Role of the Regulator}

Since IBFs have still used conventional interest rate (LIBOR/KIBOR) as the basis for all Islamic Banks internal rate of return (IRR) and had the derivative financial products with the same structure with the conventional derivative products, IBFs have inevitably been as a part of the international financial systems. As a part of the international financial systems, IBF system is influenced by international financial market portfolio. Therefore, the regulations regulated by The Fed would influence the global financial system including IBF system. The Fed has an essential role in the creation of derivative products. These regulations will create some particular policies in the financial and money market systems and they will influence the map of international financial and money market portfolios. The regulator decision made a huge impact for the system as a whole. The policy makers, in this term, are regulators may create unanticipated side effects. Thus, the IBF practitioners should anticipate for the consequences of each regulation in the short run and in the long run as well. As we learnt from the history, the creation of the Glass-Steagall act in 1933 could be a starting point that generated the other policies and then the consequences of each policy continued and burst in the next 75 years. Sterman says that 'Unanticipated side effects arise because we too often act as if cause and effect were always closely linked in time and space. But in a complex system such as financial system, 'cause and effect are often distant in time and space'. (Sterman, 2000: 11).

For IBF system, "Shari'ah Boards, being the gate-keepers of Islamic finance, play a key role in approving the appropriate products" (Ahmed, February, 2009: 9). Some experts have issued two ideas with respect to the practices of Shari'ah boards. First, establish an 
independent institution to rate the performance of Shari'ah boards. Second, establish an independent auditors which audit the practices and decisions of Shari'ah boards (Askari, Iqbal, \& Mirakhor, 2009: 36). Criticizing 'form over substance' throughout modern Islamic finance is important to do in order to reduce some confusion (Hawladar, 6 May 2009).

\subsubsection{Creation of financial derivative product, sub-prime mortgages and role of media}

Five pillars of Islamic Financial institutions above are supposed to be the fundamental differences between IBF and the conventional financial system. If the creation of all IBF products reliance on these pillars and addresses Islamic Moral Economy (IME) as Asutay (2009) suggests in his paper, IBF can be an alternative financial instrument. Nevertheless, Ahmed (2009) points out that at the instruments level, the approach in Islamic finance has been to mimic conventional products and then "it is driving Islamic finance closer to the conventional counterpart making it susceptible to similar risks and crisis" (Ahmed, February, 2009: 9). There are negative feedback effects from the financial sector to the real economy because of the creation of derivative products.

The IBF risk structure will not make any significantly differences with the conventional banking and finance, if the biggest composition of IBF product is debt-like instruments. For instance, if the IBF also have some mortgage products in their portfolio such as in any Islamic home mortgages in the US, it will create the same behavior with the conventional financial system. For the information, "Fannie Mae and Freddie Mac purchased shariah-compliant mortgage contracts from financial intermediaries, allowing providers to originate further mortgages. In 2007, Freddie Mac reportedly purchased more than $\$ 250$ million in Islamic home loans, a small but notable fraction of the enterprise's \$1.77 trillion in business activities" (Aizenman, May 13, 2008). As a part of Fannie Mae and Freddie Mac portfolios, Shariahcompliant mortgage would be influenced by the same risk with conventional mortgages.

The IBF practitioners should aware the vicious cycle and chain 
reactions in which lead the whole economy towards a systemic disaster situation. Subramanian (2009) says that the more demand for mortgage loan, the higher the aggregate mortgage-backed asset value in the banking system. These demands generate the aggregate expected mortgage payment higher than the aggregate affordable payment. At the same time, businesses decline and reduce the ability of million households to pay their mortgage. As a result, this condition leads to the collapse and bankruptcy in banking system. It demonstrates the vicious cycle in the whole system (An et al., 2009). This behavior would happen for the product with the same structure no matter whether Islamic/ethical or conventional. For that reason, IBF scholars should re-take into account the creation of derivative financial products of IBF portfolios as Heiner Flassbeck states that 'financial markets has failed to get their price right' (Flassbeck, September 1, 2009). Furthermore, he says that the players of the commodity markets have pretended to know the future price and thus, rely on the institutions which pretend to know the uncertainty in the future is gambling.

Mass media also have important role in creating opinions, spreading the news, building perspectives, advertising the products and furthermore changing the behavior in the long term. A huge impact of media must be used with the ethical way because the news can drive market behaviors.

\subsubsection{Conflict of interest of the rating agency and misplace reliance on risk management model}

Similar to the conventional financial system, if IBF relies on the rating agency, IBF will have possibilities to involve in the conflict of interest of rating agencies. As we know, IBF and the conventional banking and finance institutions used the same rating agencies. Therefore, as long as the rating agency used the same tools and indicators to evaluate the risk of IBF products with the conventional ones, the result will be the same because they used the same structure of judgments. A huge impact of the failures of rating agencies on conventional will be suffered by IBF as well. This is dilemma for IBF. If IBF products want to get the high ratings, IBF must put their portfolio in the low risk investment such as murabaha and other short-term 
debts. In contrast, the long-term portfolios, such as mudarabah and musharakah will create high risk in term of the rating agency's perspectives. As the consequences of following the rating agency perspectives, IBF are required to have short-term portfolios in order to increase their rating and simultaneously it weaken long term investments, mudarabah and musharakah. This situation makes the difficulty to escalate the proportion of profit loss sharing (PLS) portfolios as the ideal of Islamic financial products. If this situation continues, the global financial crisis stories will be repeated with the same direction to the IBF system.

Briefly, in order to get the high ratings from rating agency, the IBF players will be imposed to slice, structure and hedge of the shortterm debt in the name of financial innovation and engineering. Without questioning the fundamental philosophy behind the creation of Islamic financial products, IBF scholars and practitioners unconsciously worsen IBF's position amid severe criticism.

\subsubsection{Incentive Matters and Greedy in Financial}

There is no significantly difference the incentive structure between IBF and conventional. This situation will impose IBF to fall into the trap of incentive conflict. Since an appropriate structure of incentive has been critical in order to encourage and mitigate the moral hazard, IBF must give more attention to this factor. The policy of base salary, system bonuses, incentive of auditors and rating agencies must be identified what their effects to the firm performance particularly and to the whole system simultaneously. However, people have been overcome by the greed and ambition and they forget the fundamental of moral values, what right and what wrong. That is happened in the global financial market. Carly Fiorina says in her book, Tough Choices, people can be overcome by fear and it is a human nature because people fear with the unknown. The future is the unknown and uncertainty situation can generate people to greed. Therefore, a good system can minimize those moral hazards.

Furthermore, conventional economics assumption for human being according to Siddiqi (cited in Khan 1987: 18) are as follows: (1) The basic assumption is that man is selfish by nature and he behaves 
rationally, (2) Material progress is a supreme goal, (3) Every person has an inherent tendency to maximize his material welfare and he also has the knowledge and ability for deciding what is good for him. These assumptions are the fundamental concept for developing the capitalism. "Focusing on material pleasure as life's major driving force, Adam Smith argued that the pursuit of private interest, and not altruism, by the economic man in the market, secured a harmonious system within which social interest as maximized" (Nomani \& Rahnema, 1994: 29). As its consequence, "Neo-classical economics does not question the motive or ethics of a desire or a need as long as it is backed by the ability to pay" (Nomani \& Rahnema, 1994: 86). Fortunately, Islamic view-point is quite different on those points. Khan (1987) argues that, it is totally wrong to say that man is selfish by nature. As a matter of fact, there are numerous evidences in all civilized societies that people have been motivated by altruistic motives. Altruism is a fact of life. Islam persuades people to make sacrifices for others. Zakah, infaq, shadaqah and waqf are the form of Islamic philanthropy. Caring for others is a paramount value of Islamic society (Khan, 1987: 18). God repeatedly invites Muslims to be altruistic and charitable and promises great material recompense to those who part with their wealth in the cause of God (Nomani \& Rahnema, 1994: 26). Based on the facts above, there are more rooms in the society, including banking and financial society, for avoiding greedy in IBF system.

\subsection{Having a big picture of Islamic Banking and Finance system}

Sharpen the ability to see the system as a whole using system thinking and dynamics paradigm is pivotal. Questioning all the fundamental principles and philosophy behind the creation of IBF product and trying to forecast what the unintended consequences in the future must to do. The shariah interpretations vary and may create confusion for those who fail to look at the IBF system holistically. On one hand, the relationship among IBF systems is dynamics and on the other the risk profiles are also dynamics. Hence, risk management in Islamic Financial institutions is far more of a serious issue when compared to conventional financial institutions (Akkizidis \& Khandelwal, 2008). In short, this crisis provides evidence that the 
simplifying assumptions on which much of modern macroeconomics is based were not useful in explaining real world developments.

Learnt from financial crisis, a mental model of "wait until it's a major problem" seems to dominate decision-making process (Graham, 2009). We always late to understand and then anticipate because we will act when it becomes a serious problem and we will pay the enormous price for it. Since trust has become a key word for IBF system, the price of failing of IBF will spread to the vast dimensions that are not expected. Trust is a key word for IBF. Akkerman said 'Trust is easier depleted than grown. He, then, says that trust "comes by foot but leaves on horseback" (Akkermans, 2008). Reputation is very important for IBF system. Askari says that reputational risk arises when there is a gap between the corporate behavior and the expectations of the stakeholders. The larger this gap is, the larger the exposure is to reputational risk (Askari et al., 2009: 153).

Inability to see the big picture remembers us on a John Godfrey Saxe' (1816-1887) story about 'The Six Blind Men and the Elephant'. Each man disputed loud and long to defend his own opinion about what the Elephant looks like and we know they all were wrong because no one of them has seen. The Islamic scholars should pay more attention to the structure of Islamic financial products and their position among the broader structure of financial systems as an integrated system.

\section{CONCLUSIONS}

Based on the holistic approach, system thinking and dynamics paradigm in understanding the problem of a system, this paper investigates the critical factors which make Islamic scholars aware of the problem of an integrated and interdependent financial system and to assure them can be avoided in the future. Understanding the role of regulators, mass media, derivative financial products, greedy or unethical people, conflict of interest of rating agency, incentive matters, misplace reliance on risk management model is critical for developing intuition about the evolution of the financial system which simultaneously stimulate the global financial crisis overtime. Sharpen the intuition to see the bigger picture of system is very essential. To do 
so, we have to change the way people see the system. The process thinking rather than partial or snapshot thinking must be enhanced. Asking the questions what the fundamental philosophy of each policy and simulating the impact of each policy in the future are pivotal to do by Islamic scholars and practitioners. However, the same structure of the system will create the same behavior and furthermore the same consequences. Unanticipated consequences experiences of the global financial system will spread to IBF system if both systems have the same structure. Risk management of IBF is not just numbers but more than that. It is highly related to human behavior in a complex system. 


\section{REFFERENCES}

Ahmed, H. (2009, February). Financial Crisis, Risks and Lessons for Islamic Finance. In paper written for Harvard-LSE Workshop on Risk Management: Islamic Economic and Islamic Ethico-Legal Perspectives on the Current Financial Crisis: London School of Economics.

Aizenman, N. C. (2008, May 13). A Higher Law for Lending. The Washington Post.

Akkermans, H. (2008). The 5th Wave "Travail, transparency and trust": Understanding the dynamics of buyer-supplier relations. Supply Network Dynamics. Retrieved July 18, 2009.

Alger, D. (1998). Megamedia: How Giant Corporations Dominate Mass Media, Distort Competition, and Endanger Democracy. Oxford: Rowman \& Littlefield, Oxford.

Allen, W., \& Wood, G. (2006). Defining and achieving financial stability. Journal of Financial Stability, June, 152-172.

An, L., Subramanian, D., \& King, A. (2009). On modeling some essential dynamics of the subprime mortgage crisis. Paper presented at the Proceeding of the 27th International Confeence of the System Dynamics Society, Albuquerque, New Mexico, USA.

Askari, H., Iqbal, Z., \& Mirakhor, A. (2009). New Issues in Islamic Finance and Economics: Progress and Challenges. Singapore: John Wiley \& Sons (Asia) Pte.Ltd.

Asutay, M. (2007). Conceptualisation of the Second Best Solution in Overcoming the Social Failure of Islamic Banking and Finance: Examining the Overpowering of Homoislamicus by Homoeconomicus. IIUM Journal of Economics and Management 15(2), 167-195.

Asutay, M. (2009). An Introduction to Islamic Moral Economy (IME). Paper presented at the Durham Islamic Finance Summer School 2009, Durham University, United Kingdom.

Balzac, H. (1850). Lettres a l'Etrangere (Vol. 2). Paris: cited in Tresor de la Langue Francaise (Paris: Institut National de la Recherce Scientifique, 1976). 
British-Academy. (2009, July 22). A letter for The Queen Question [Electronic Version]. Retrieved August 2, 2009 from http://media. ft.com/cms/ 3e3b6ca8- 7a08-11de- b86f00144feabdc.

Chapra, M. U. (2000). The Future of Economics, An Islamic Perspectives. Markfield, Leicester, United Kingdom: The Islamic Foundation.

Chapra, M. U. (Ed.). (2008). The Islamic Vision of Development in the Light of Maqasid al-Shari'ah. London: The International Institute of Islamic Thought.

Checkland, P. (1981). System Thinking, System Practice. Chichester, Sussex: John Wiley \& Sons Ltd.

Clemson, B. (1984). Cybernetics: A New Management Tool. Abacus: Turnbridge Wells.

Coyle, R. G. (1996). System Dynamics Modelling: A Practical Approach. London: Chapman \& Hall.

Cumming, C., \& Hirtle, B. J. (2001). The Challenges of Risk Management in Diversified Financial Companies. Economic Policy Review, Federal Reserve Bank of New York, 7, 1-17.

Flassbeck, H. (2009, September 1). Responding to the Global Crisis \& Climate Change Mitigation \& Development. On LSE's Podcast Lecturer Series London, UK: London School of Economics Podcast Lecturer Series.

Forrester, J. W. (1971a). Counterintuitive behavior of social systems. Technology Review, 73(3), 52-68.

Graham, A. K. (2009). Four Grand Challenges for System Dynamics. Paper presented at the 27th of International Conference of System Dynamics, Albuquerque, New Mexico, USA.

Grant, R. W., \& Sugarman, J. (2004). Ethics in Human Subjects Research: Do Incentives Matters? Journal of Medicine and Philosophy, 29(6), 717-738.

Hawladar, K. (6 May 2009). The Future of Sukuk: Substance over Form? Understanding Islamic securitisation, Asset-Backed and AAOIFI principles [Electronic Version]. International Structure Finance, Europe, Middle East, Africa, Special Comment. 
Khan, M. A. (1987). Methodology of Islamic Economics. Journal of Islamic Economics, 1(1), 17-34.

Maani, K. E., \& Maharaj, V. (2001). System Thinking and Complex Problem Solving: A theory building empirical study. Proceeding of the 19th International Conference of the System Dynamics Society, 24.

Nomani, F., \& Rahnema, A. (1994). Islamic Economic Systems. London \& New Jersey: Zed Books Ltd.

Protter, P. (2008, September 29). The Financial Meltdown, How did we get in this mess? Retrieved August 5, 2009.

Radianti, J. (2008). Reflection on Research Methods of the Dynamic Modeling of the Black Markets for Vulnerabilities. Philosophy of Science (Department of Geography, University of Bergen), 16.

Richardson, G. P. (1991). Feedback Thought in Social Science and System Theory. University of Pennsylvania Press.

Richmond, B. (1993). System Thinking: Critical Thinking Skills for the 1990s and Beyond. System Dynamics Review, 9(2), 113-133.

Richmond, B. (1994). Competing in the 90's: System Thinking, ithink and Organisational Learning. In Introduction to Systems Thinking and ithink (pp. 1-21).

Richmond, B. (1997a). Dynamic Thinking: A Behavioral Context. The System Thinker, 8(6).

Richmond, B. (1997b). Forest Thinking. The System Thinker, 8(10), 6-7.

Richmond, B. (1997c). System-as-Cause Thinking. The System Thinker, 8(8), 6-7.

Richmond, B. (1997d). The "Thinking" in System Thinking: How Can We Make it Easier to Master. The System Thinker, 8(2), 1-5.

Richmond, B. (1998). Operational Thinking. The System Thinker, 9(2), 6-7.

Richmond, B. (2000). The "thinking" in system thinking. USA: Pegasus Communication, Inc.

Schoderberk, M. C. (1980). Management Systems; Conceptual considerations. Dallas: Business Publications. 
Senge, P. M. (1990). The Fifth Discipline: The Art and Practice of the Learning Organization ( $1^{\text {st }}$ ed.). New York: Doubleday/Currency.

Senge, P. M. (2006). The Fifth Discipline: The art and practice of the learning organization (Revised and Updated ed.): Random House Business Books.

Siddiqi, M. N. (2008). Obstacles of Research in Islamic Economics. Paper presented at the 7th International Conference in Islamic Economics, King Abdulaziz University.

Siddiqi, M. N. (2008, October). Current Financial Crisis and Islamic Economics [Electronic Version]. Retrieved October 2, 2009.

Standard \& Poor's. (2009). Islamic Finance Outlook 2009 [Electronic Version].

Sterman, J. D. (2000). Business dynamics: system thinking and modeling for a complex world. McGraw-Hill Higher Companies Inc.

Sushil. (1993). System Dynamics, A Practical Approach for Managerial Problems. New Delhi: Wiley Eastern Limited.

The Financial Services Authority. (2009, March). The Turner Review, A regulator response to the global banking crisis. London.

Website : http://blog.mint.com/blog/wpsvcontent/uploads/2008/11/ visualguidecrisis2.jpg. Retrieved June 5, 2014.

Website: www.fsa.gov.uko.

White, W. (2009, December). Modern Macroeconomics Is on The Wrong Track [Electronic Version]. Financial and Development: A Quarterly Publication of the IMF, 46, 16.

Wolstenholme, E. F. (1990). System Enquiry, A System Dynamics Approach. Chichester: John Wiley \& Sons. 